\title{
THE EFFECT OF COTTON PLANT SPACING ON IMPORTANT INSECT PESTS AND THEIR RELATED PREDATORS AND YIELD \\ Mesbah, A.H. ${ }^{*}$; M.M. El-Husseini ${ }^{* *}$ and Amal A. El-Zoghbey* \\ * Plant Protection Research Institute, Department of Biological Control, Agricultural Research Center Giza, Egypt \\ ** Center of Biological Control AND IPM, Fac. of Agric., Cairo Univ. Giza, Egypt
}

\section{ABSTRACT}

Field study was carried out at Desuq district, Kafr El-Sheikh Governorate during two successive seasons, 2007 and 2008 to determine the effect of cotton plant spacing on the important insect pets and their associated predators as well as the cotton yield.

The results showed that the important insect pests were the percing and sucking insect pests (Bemisia tabaci (Genn.), Aphis gossypii (Glov.), Empoasca lybica deBarg, and Thrips tabaci), Spodoptera littoralis (Boisd.), Pectinophora gossypiella (Sound.) and Earias insulana Lind. . The cotton plant spacing had significant effect on piercing sucking insect pests, where the population of these pests increased in the narrow bed with rate $25 \mathrm{~cm}$ inter and $59.16 \mathrm{~cm}$ intra, followed by narrow row with the same rates of plant spacing. While, in the wider rates $(50 \mathrm{~cm}$ inter and $118.32 \mathrm{~cm}$ intra) were lowest. As for other insect pests, there were no significant differences between these pests in the four spacing rates.

The important predators were the coccinelids, (Coccinella undecimpunctata, and Scymnus interruptus Mals.), Paederus alfierii, Syrphus spp., Orius spp. and Chrysoperla canrea Steph. The predators correlated only with their prey but had no correlation with plant spacing. On the other hand, there was significant relationship between coccinellid predators and aphid and between Chrysoperla carnea Steph. and both aphid and whitefly as well as between Paederus alfierii, Kokh and Spodoptera littoralis Boisd.

The results also indicated that the significant increasing of cotton yield in narrow row spacing inter-25 cm and intra- $59.16 \mathrm{~cm}$ (11.2 and 9.1 quintals/fed. in the two seasons, respectively followed by the same spacing rate on bed ( 9.8 and 8.7 quintal/fed., respectively), while in wide spacing (50 cm. inter-row) 9.5 and 7.9 quintal/fed., respectively and in wide bed spacing 8.5 and 7.2 quintal/fed. in the two seasons, respectively.

Keywords: Cotton, Insect Pests, Predators, Cotton yield.

\section{INTRODUCTION}

Cotton (Gossypium barbadense L.) is the main cash money crop in Egypt. Cotton plants are subject to infestation with several insect pests throughout the growing season, beginning from seed germination up to harvest, causing a serious damage to the yield quantity and quality (Ahmed, 2004). Several investigations controlled the cotton pests by many methods throughout integrated pest management. On the other hand, several researches were applied for agricultural methods and plant spacing to find their effect on the yield, but these investigations which to deal with the pervious methods with the pest control were very rarely. So this work 
Mesbah, A.H. et al.

aimed to evaluation the effect of cotton plant spacing on the insect pests and their related predators as well as on the cotton yield.

MATERIALS AND METHODS

The study was carried out at Desuq district, Kafr El-Sheikh Governorate during two successive cotton growing seasons; 2007 and 2008. One feddan was chosen for sampling. The experimental field was divided into four equal parts (treatments). Cotton variety Giza 86 (recommended by Ministry of Agriculture) was cultivated on $4^{\text {th }}$ week of March, in both seasons. The first treatment was sown on row of $25 \mathrm{~cm}$. inter-spacing and $59.16 \mathrm{~cm}$. intra-spacing. The second one was sown on bed of $25 \mathrm{~cm}$ inter-spacing and 59.16 intra-spacing. The third one was sown on row of $50 \mathrm{~cm}$ inter-spacing and 59.16 intra-spacing. The fourth was sown on bed of $25 \mathrm{~cm}$ inter-spacing and 118.32 intra-spacing. Direct counts of insect pests and their associated predators were taken weekly by the end of May until the first week of October and the sample contained 10 plants except in case of Bemisia tabaci and bollworms. B. tabaci, immatures stages (eggs, larvae and pupae) were counted in $20 \mathrm{in}^{2}$ of the cotton leaves (10 leaves $\mathrm{x} 2 \mathrm{in}^{2}$ ). As for bollworms (Pectinophora gossypiella and Earias insulana), the sample contained 10 green bolls starting from July $1^{\text {st }}$ until the last week of September. In the laboratory, the bolls were examined and considered infested when containing one larva or more of any of the two bollworm species. (Mesbah 2007). At the end of every season, the yield of each treatment was estimated.

The data were subjected for proper statistical analysis and Duncan's Multiple range (DMR) test at $5 \%$ probability was applied to find out the impact of plant spacing on insect pests and their associated predators and on the cotton yield.

\section{RESULTS AND DISCUSSION}

\section{Effect of plant spacing on insect pests:}

Data in Table (1) showed that the cotton plant spacing had a highl effect on insect pests, especially piercing sucking insect pets, Bemisia tabaci (Genn.) immature stages, Aphis gossypii Glov., Empoasca lybica deBarg and Thrips tabaci Lind. The cotton plants in narrow bed (NB $25 \mathrm{~cm}$ inter-spacing) possessed high numbers of the piercing sucking insect pests, 1412 and 1249 ind./180 plants and 200 in $^{2}$ (B. tabaci immatures in the two seasons, respectively. The NR (narrow row spacing $25 \mathrm{~cm}$ ) possessed 1197 and 1125 ind./180 plant and $200 \mathrm{in}^{2}$. The lowest numbers of the piercing sucking insect pests were recorded on B. intra-double plant spacing (892 and 698 ind./180 plants and $100 \mathrm{in}^{2}$ in the two seasons, respectively. In contrast Spodoptera littoralis Boisd. larvae were recorded with high numbers on row-inter double plant spacing, 147 and 128 larvae/180 plants in the two seasons, respectively. Meanwhile, the lowest rate of $S$. littoralis larvae was recorded on NR (narrow plant spacing, 25 $\mathrm{cm}$ ), where it was 57 and 66 larvae/180 plants during 2007 and 2008 
seasons, respectively. As for bollworm, E. insulana and $P$. gossypeilla, the normal bed had the high infestation with two pests especially in 2007 season, while, the lowest infestation was occurred on row inter-row double plant spacing (50 cm inter-spacing) Table (1).

Table (1): Population density of cotton insects as influenced by plant spacing during 2007 and 2008 seasons.

\begin{tabular}{|l|c|c|c|c|c|c|c|c|}
\hline \multirow{2}{*}{ Treatments } & \multicolumn{7}{|c|}{ Insect pests/180 cotton plants } \\
\cline { 2 - 9 } & $\begin{array}{c}\text { Piercing } \\
\text { sucking insect } \\
\text { pests }\end{array}$ & \multicolumn{2}{c|}{$\begin{array}{c}\text { S. littoralis } \\
\text { Larvae }\end{array}$} & \multicolumn{2}{c|}{$\begin{array}{c}\text { E. insulana } \\
\text { Larvae }\end{array}$} & $\begin{array}{c}\text { P. gossypeilla } \\
\text { Larvae }\end{array}$ \\
\cline { 2 - 9 } & $\mathbf{2 0 0 7}$ & $\mathbf{2 0 0 8}$ & $\mathbf{2 0 0 7}$ & $\mathbf{2 0 0 8}$ & $\mathbf{2 0 0 7}$ & $\mathbf{2 0 0 8}$ & $\mathbf{2 0 0 7}$ & $\mathbf{2 0 0 8}$ \\
\hline NR $(25 \mathrm{~cm})$ & 1197 & 1125 & 57 & 66 & 2 & 1 & 1 & 2 \\
NB $(25 \mathrm{~cm})$ & 1412 & 1249 & 110 & 98 & 2 & 3 & 2 & 3 \\
R. inter-d & 987 & 728 & 77 & 66 & 2 & 0 & 1 & 1 \\
B intra-d & 892 & 698 & 147 & 128 & 2 & 2 & 1 & 2 \\
\hline
\end{tabular}

Piercing sucking pests = Jassid, Aphid, Bemisia tabaci (immatures/200 in ${ }^{2}$ ) and thrips

** P. gossypiella and $E$. insulana larvae/100 green bolls

NR $=$ Normal row,

NB $=$ Normal bed

R. inter-d = row-inter double spacing

B. intra-d = intra double spacing

Table (2): Population density of insect predators associated with cotton insect pests as influenced by plant spacing during 2007 and 2008 seasons.

\begin{tabular}{|l|c|c|c|c|c|c|c|c|c|c|}
\hline \multirow{2}{*}{ Treatments } & \multicolumn{8}{|c|}{ Insect predators/180 cotton plants } \\
\cline { 2 - 11 } & Coccienllids & \multicolumn{2}{|c|}{$\boldsymbol{P}$. alfierii } & \multicolumn{2}{c|}{$\begin{array}{c}\text { Syrphus } \\
\text { spp. larvae }\end{array}$} & \multicolumn{2}{c|}{ Orius spp. } & \multicolumn{2}{c|}{$\begin{array}{c}\text { C. carnea } \\
\text { larvae }\end{array}$} \\
\cline { 2 - 11 } & $\mathbf{2 0 0 7}$ & $\mathbf{2 0 0 8}$ & $\mathbf{2 0 0 7}$ & $\mathbf{2 0 0 8}$ & $\mathbf{2 0 0 7}$ & $\mathbf{2 0 0 8}$ & $\mathbf{2 0 0 7}$ & $\mathbf{2 0 0 8}$ & $\mathbf{2 0 0 7}$ & $\mathbf{2 0 0 8}$ \\
\hline NR $(25 \mathrm{~cm})$ & 30 & 33 & 2 & 2 & 0 & 2 & 5 & 1 & 4 & 3 \\
NB $(25 \mathrm{~cm})$ & 36 & 32 & 2 & 2 & 2 & 3 & 2 & 3 & 5 & 3 \\
R. inter-d & 28 & 30 & 1 & 0 & 0 & 1 & 0 & 2 & 1 & 2 \\
B. intra-d & 27 & 26 & 3 & 2 & 0 & 0 & 2 & 1 & 1 & 1 \\
\hline
\end{tabular}

Piercing sucking pests $=$ Jassid, Aphid, Bemisia tabaci $\left(\right.$ immatures/200 in $^{2}$ ) and thrips

** P. gossypiella and $E$. insulana larvae/100 green bolls

NR = Normal row, $\quad$ NB $=$ Normal bed

R. inter-d = row-inter double spacing $\quad B$. intra-d = intra double spacing

Statistical analysis revealed high significant differences between $B$. tabaci, A. gossypii, E. lybica and T. tabaci (piercing and sucking insect pests) in the four treatments during the two study seasons. In spite of the differences in the numbers of $S$. littoralis, $E$. insulana and $P$. gossypeilla in the different treatments there were no significant differences between these pests. The present results are in conformity with those of Arif et al. (2006) who found that the populations of jassid, whitefly and thrips were higher at lower plant spacing. Also, the present finding are in conformity with shoes of Butter et al. (1992), Mohite and Uthamasamy (1999) who recorded that the population of jassid was higher at lower plant spacing. However, the present findings are not in agreement with those of Sohi et al. (1995) who reported that incidence of jassid was not significantly affected with spacing. 
Mesbah, A.H. et al.

The present findings of whitefly are in conformity with those of Seif (1980). From available literature, no investigation was handled the effect of plant spacing on cotton leaf worm or bollworms.

\section{Effect of plant spacing on insect predators:}

As data shown in Table (2), the coccinellid predators (Coccinella undecimpunctata and Scymnus interruptus) were the most abundant predators in the four treatments. The highest numbers of coccinellids were recorded on NB plot, 36 and 32 predators $/ 180$ plants in the two seasons, respectively followed by NR, 30 and 33 predators per 180 plants in two seasons, respectively. The lowest rate of predator numbers were detected on B. intra-d, 27 and 26 coccinellids/180 plants, respectively. In contrast for $P$. alfierii was recorded with high number on $\mathrm{B}$. intra-d while $C$. carnea was higher on NB spacing. As for Syrphus spp. and Orius spp. They were relatively higher on NR and NB plant spacing.

Statistical analysis revealed no significant variations among the predators in the four replications. On the other hand there were highly significant correlation between coccienllids and aphid and between $C$. carnea and both aphid and whitefly as well as between $P$. alfierii and $S$. littoralis. The present data revealed no effect of plant spacing on the insect predators, where the key factor of the predators were the occurrence of their prey not the plant spacing.

\section{Effect of plant spacing on the cotton yield:}

Fig. (1) showed that the highest cotton yield was obtained from NR (normal row spacing $25 \mathrm{~cm}$ ) in the two seasons, 11.2 and 9.1 quintals/fed., respectively followed by NB, 9.8 and 8.7 quintal/fed., respectively. The lowest yield was recorded in B. intra-double spacing (7.2 and 7.9 quintal/fed., respectively. Statistical analysis revealed highly significant difference between NR spacing and other treatments. On the other hand, no significant differences were found among the other three treatments.

It is noteworthy that the agricultural practices were easier to be done in wide spacing (bed intra-spacing $1187.3 \mathrm{~cm}$ and row-inter-spacing, $50 \mathrm{~cm}$ ) than in narrow row spacing (NB and NR spacing. 


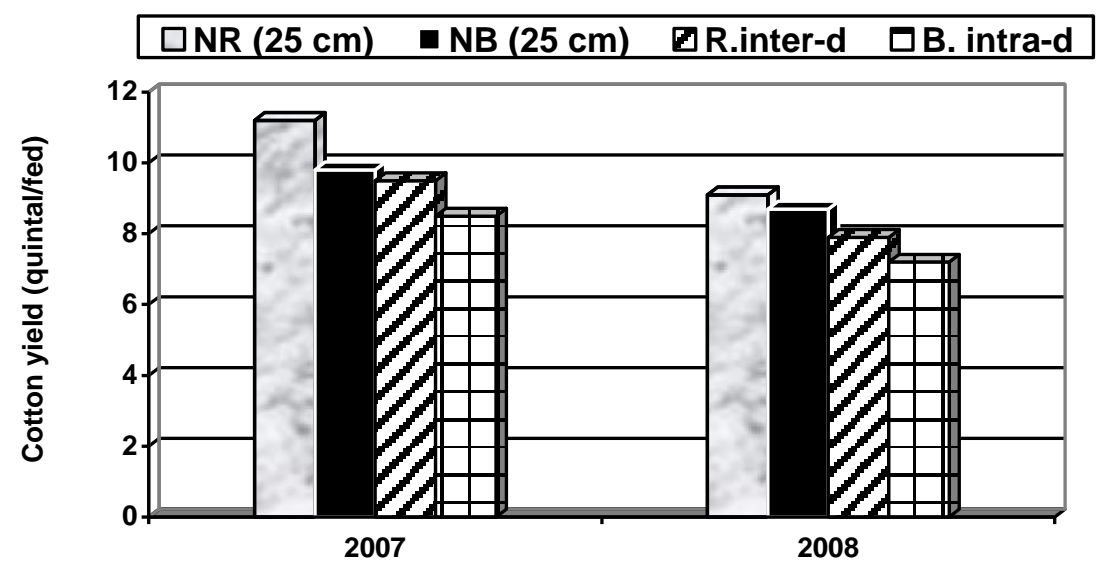

Fig. (1): Cotton yield as influenced by four cotton spacing.

The size of bolls and their numbers were more in the wide plant spacing, as well as the bolls opening was highly in the wide spacing plants. The previous characters may be considered in the breeding programs. The present finding are in agreement with those of Heitholt et al. (1992) and Steglich et al. (2000) who recorded that narrow row spacing increases total seasonal light interception, which can potentially increase cotton yield. The finding was found by Wiatrak et al. (1998) and Cawley et al. (1999) who found that the UNR (Ulter-narrow row) cotton had equal or higher yields than wide row cotton. The present results are not in agreement with those of Jones et al. (2000) who found that lint yields were similar for cotton grown in 19, 38, 76 and $102 \mathrm{~cm}$ row spacing. Also, Witten and Cothren (2000) found eight cultivars yielded higher in a $38 \mathrm{~cm}$ row spacing than in a $19 \mathrm{~cm}$ row spacing because boll size were greater in the $38 \mathrm{~cm}$ row spacing. Finally, Boquet (2005) reported that ultra-narrow row spacing (UNR) of $25 \mathrm{~cm}$ or less may be viable alternative to wide-row spacing and increase in plant density decreased boll number and individual boll weight, he also found that maximum yields of UNR cotton were attained from plant densities in the range of 1280000-256000 ha.

\section{REFERENCES}

Ahmed, R.M.E. (2004). Studies on the role of natural enemies in controlling some cotton insects at Dakahlia Governorate. M.Sc. Thesis, Fac. of Agric. Mansoura Univ. pp. 131.

Arif, M.J.; M.D. Gogi, M. Miraza, K. Zia and F. Hafeez (2006). Impact of plant spacing and abiotic factors on population dynamics of sucking insect pests of cotton. Pakistan J. Biol. Sci.. 9(7): 1364-1369.

Boquet, D.J. (2005). Plant Density and Nitrogen fertilizer Rates. American Society Agron. J. (97): 279-287.

Butter, N.S.; A.S. Brar, J.S. Kular and T.H. Singh (1992). Effect of agronomic practices on the incidence of key pests of cotton under unsprayed conditions. Ind. J. Entomol., 54: 115-123. 
Cawley, N.; K. Edmisten; R Wells and A. Stewart (1999). Evaluation of ultra narrow row cotton in North Carolina. p. 558-559. In P. dugger and D. Richter (ed) Proc. Beltwide cotton Conf., Orlando, FL. 3-7 Jan. 1999 National Cotton Council, Memphis, TN.

Heitholt, J.J.; W.T. Pettigrew and W.R. Meredith, Jr. (1992). Light interception and lint yield of narrow-row cotton. Crop Sci. 32: 728733.

Jones, J.M.A., C.E. Smipes and G.R. Tupper (2000). Management systems for transgenic cotton in ultra-narrow rows. P. 714-717. Inp. Dugger and D. Richter (ed.) Proc. Beltwide cotton Conf., San Antonio, Tx. 48 Jan., 2000. National cotton council, Memphis TN.

Mesbah, A.H. (2007). Integrated pest management on major cotton Insect pests at Kafr El-Sheikh Region, Egypt. J. Agric. Res., 85(6): 20272049.

Mohite, P.B. and S. Uthamasamy (1997). Influence of varied spacings and fertilizer levels on the incidence of key pests of cotton in Tamil Nadu. Ind. J. Agric. Res., 31: 222-226.

Seif, A.A. (1980). Seasonal fluctuation of adult population of whitefly, Bemisia tabaci Genn. on cotton and its relationship with weather parameters. J. Cotton Res. Dev., 5: 181-189.

Sohi, A.S.; J. Singh and H.S. Mann (1995). Impact of plant spacing on incidence of insect pests and seed cotton yield of American cotton. J. Insect Environ. Sci., 1: 15-16.

Steglich, E.M., T.J. Gerik; J. Kiniry; J.T. Cothren and R.G. Lemon (2000). Change in the light extinction coefficient with row spacing in upland cotton. p. 606-608 Imp. Dugger and D. Richter (ed.) Proc. Beltwide cotton Conf. San Antonio, tx. 4-8 Jan. National Cotton Council, Mephis, TN.

Wiatrak, P.J.; D.L. Wright; J.A. Pudelko; B. Kidd and W. Koziara (1998). Conventional vs. ultra-narrow row (UNR) cotton in different tillage systems. In T.C. Keisling (ed.) Proc. 21st Annu. Southern Conservation tillage conf. for sustainable Agric., North Little Rock, AR, 15-17 July 1998 Arkansas Agric. Exp. Stn. Spec. Rep. 186.

Witten, T.K. and J.T. Cothren, (2000). Varietal comparisons in ultra narrow row cotton (UNRC). p. 608. In. P. Dugger and Richter (ed.) Proc. Beltwide cotton Conf, San Antonio, Tx. 4-8 Jan. 2000 National Cotton Council, Memphis, TN.






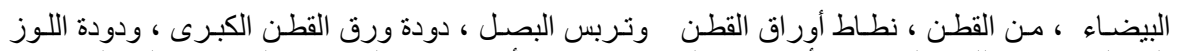



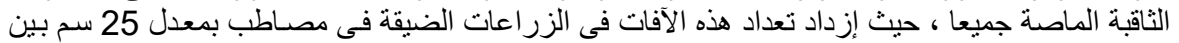

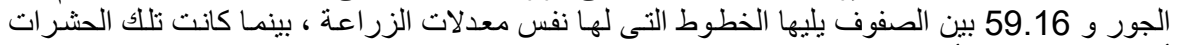

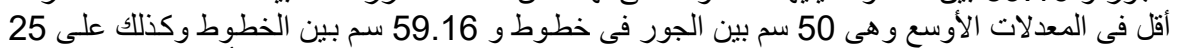



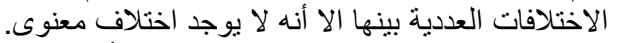

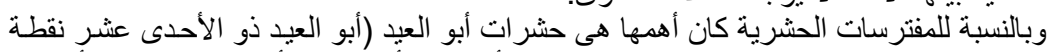

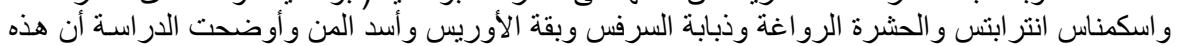

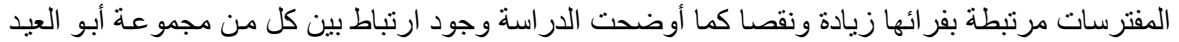

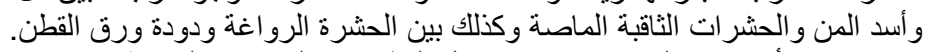

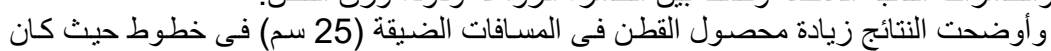

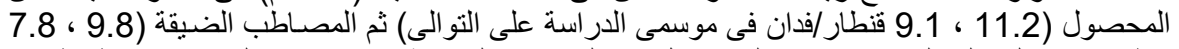

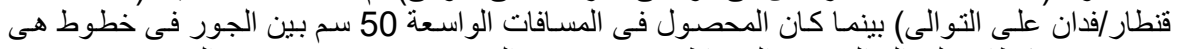

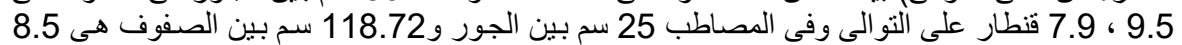

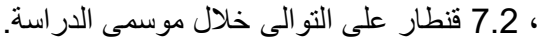

